\title{
Application in Payment to Support Small, Micro, and Medium Enterprise
}

\author{
Sri Dewi Anggadini \\ Department of Accounting, Universitas Komputer Indonesia \\ Email: timkonferensi4@gmail.com

\section{Wulandari Dianti Putri} \\ Department of Accounting, Universitas Komputer Indonesia \\ Email: timkonferensi4@gmail.com
}

\section{ABSTRACT}

This study aims to determine the existence of e-Money and have an impact on increasing income in Micro, Small and Medium Enterprises. The research method implemented in this research is descriptive qualitative. Most people, including MSME entrepreneurs, think that the benefits of making e-Money digital payments are very helpful in processing transactions in the form of non-cash and can be stored on electronic devices so as to minimize the risk of theft and make it simpler. E-Money or electronic money is involved in a type of digital payment that involves the use of a computer network which is one of the technological advances. The results of this study are that E-money has many benefits for consumers, especially for MSMEs (Micro, Small, and Medium Enterprises) because its existence will shorten time and cost and is an effort to develop MSME businesses so that MSME business processes can be implemented effectively, efficiently and economically.
\end{abstract}

\section{Keywords: E-money, SMEs, MSMEs.}

Received: 1 April 2021;

Accepted: 4 June 2021;

Publish: June 2021

\section{How to Cite:}

Anggadini, S.D., Putri, W.D. (2021). Application in Payment to Support Small, Micro, and Medium Enterprise. Journal of Business and Behavioural Entrepreneurship, 5(1), 142-148. https://doi.org/10.21009/JOBBE.005.1.09 


\section{INTRODUCTION}

This study aims to determine whether e-Money boosts income in Small Micro Medium Enterprises. Money is an object that is portable, dividable, durable, and stable. Money has three main functions which are identified as a medium of exchange, a store of wealth or value, and a unit of account. Since it begins around 15,000 years ago, money has undergone an ongoing process in the form of both change and modus operandi. Such changes usually occur about major transformations in economic functioning (Soegoto, Eddy Soeryanto, 2014). Globalization and internationalization of relations together with virtual economic ties have become more stable and the emergence of necessary new technologies and information and communication resources (Bernal, J. 2017).

This research is important to do because there are often problems with MSMEs that do not have clarity in recording cash receipts and disbursements so it is necessary to implement a payment system with a digital system, namely through e-Money so that it is hoped that this e-Money payment can help in the transaction process, especially non cash and can be stored in electronic devices so as to minimize the risk of theft. Emoney functions as a non-cash payment instrument and has several advantages that promote efficiency in conducting transactions compared to manual payment instruments (Husnunnida, M., \& Alfiana, F. 2019 ; Soegoto \& Suprianti, 2019). Thus, as a new payment instrument in Indonesia, E-money aims to reduce the growth rate of cash by utilizing the convenience offered by the transaction tool. Examples of typical interpretations of electronic money considering each of the three approaches are as follows: 1) Electronic money payments with their use must be once and final; 2) The monetary value, represented by the request of the issuer, keep on the device and then issued after receiving funds in an amount not less than the volume of liabilities assumed then must get to pay not only by the issuer but also by other companies; 3) Saving money in electronic devices can be well received by various parties so that it is very easy and useful. Various researches in the field of entrepreneurship argue and respond positively to the existence of this E-money transaction and will greatly affect rapid economic growth, create jobs, reduce poverty, be motivated to innovate and minimize imbalances in the economy, especially in suburban or rural areas that really need more attention. in an effort to develop the region (Kurniawan \& Valentina, 2019).

Evidence that MSMEs persisted when the economic crisis hit the world, which had an impact on worsening economic conditions in Indonesia, occurred in 1997 and 1998. (Lestari \& Tumiwa, 2018). This study aims to determine the existence of eMoney can increase income in busang businesses, one of which is Micro, Small and Medium Enterprises. This study uses a qualitative descriptive method. It is acknowledged by most MSME entrepreneurs that transactions using E-money are very easy and provide many benefits and minimize risks such as theft and loss.

\section{RESEARCH METHOD}

This study used descriptive quantitative method. Survey was taken to 12 students who use e-Money in buying products at SMEs. By using this method, a picture of the use and efficacy of E-money in everyday life can be depicted. 


\section{RESULTS AND DISCUSSIONS}

The latest technological developments have made it possible for alternative uses of cash in small amounts of transactions. Electronic money was authentic born when prepaid cards by non-banks began to circulate in a wider range of acceptors outside the original issuer (Rungani \& Potgieter 2018 ; Mustofa, 2019). Various groups have ease in accessing information in many ways and can enjoy the facilities of digital technology release and in a controlled manner.

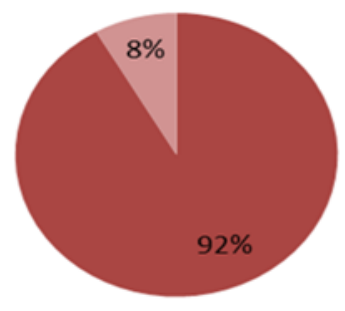

$$
\begin{aligned}
& \square \text { Yes } \\
& \square \text { No }
\end{aligned}
$$

Figure 1. E-Money User

It can be seen that $92 \%$ of $100 \%$ use e-Money as a tool for transactions. They choose e -Money because it is practical, flexible, makes it easy for users to pay, and if you use e -money get massive promos that are rarely offered.

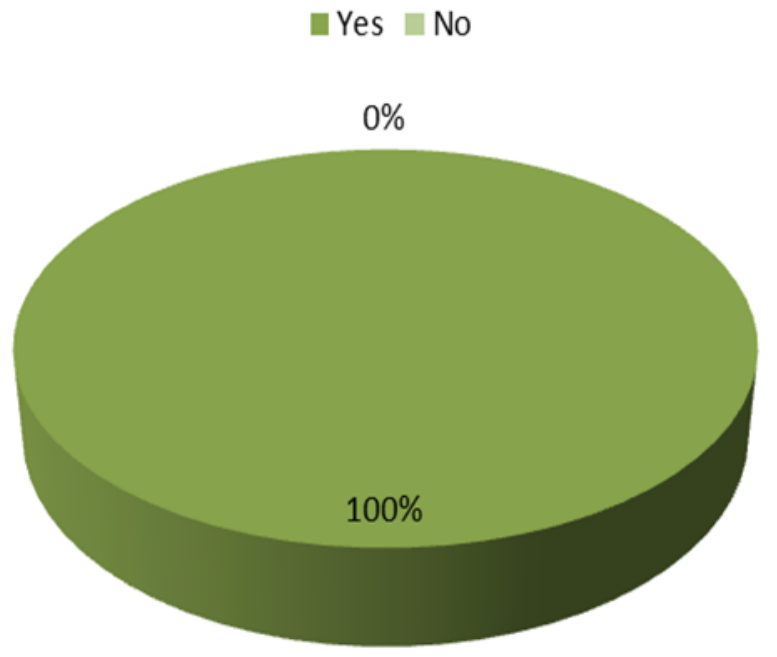

Figure 2. E-Money's ease of use

$100 \%$ of students answered that E-money is a payment tool that is helpful in transaction. E-money also provides convenience, speed, and practicality in conducting various payment transactions. So, you don't have to bother preparing cash to pay (Lotz \& Vasselin, 2019). In addition, there is no need to accept change in the form of goods, because with E-Money, the merchant only needs to clear directly through the computer network. Some people may be familiar with SMEs, but some are unfamiliar with 
SMEs and they believe that E-Money can be used by SMEs because e-money users are increasing rapidly and are suitable for all types of businesses that are being carried out by SMEs (Soegoto \& Cica, 2018). Finally, it is applicable because it can be used for a variety of small-value, high-frequency mass transactions, for example, toll fees, paying for transportation tickets, parking, fast food, and others.

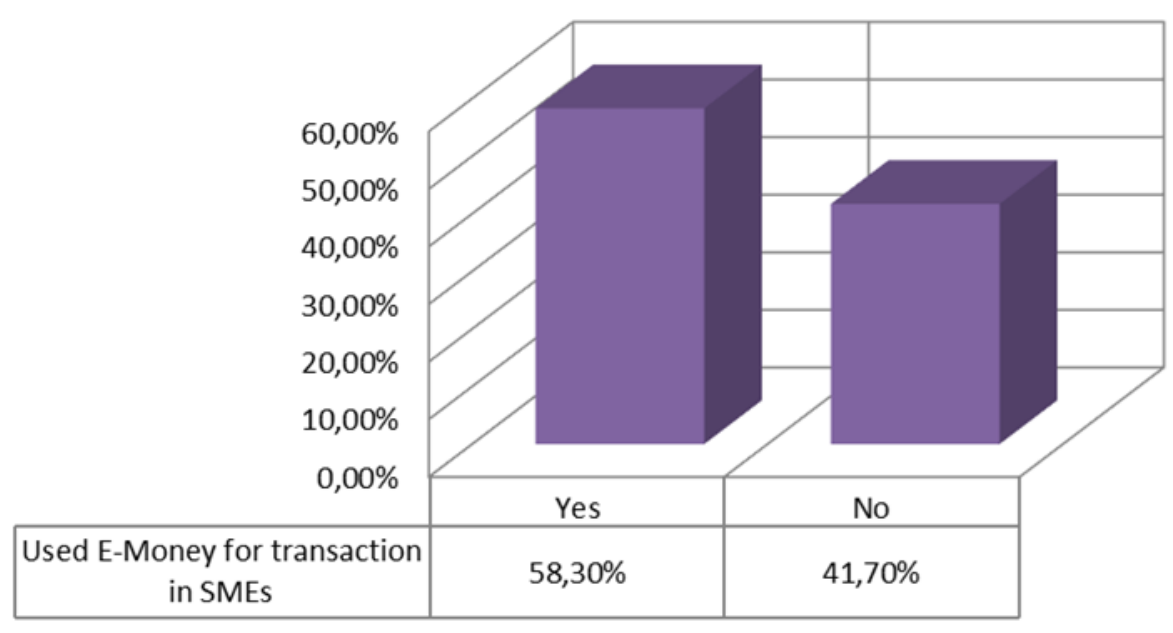

Figure 3. Used E-Money for Transaction in SMEs

Some people may be familiar with SMEs, but some are unfamiliar with SMEs and they believe that E-Money can be used by SMEs because e-money users are increasing and are suitable for all types of businesses that are being carried out by SMEs. Among them, 58,30\% several students have made payment transactions at a store, shop, kiosk to the SME market and use e-money to payment (Pratiwi \& Dewi, 2018). The impact of e-Money is to make digital currencies more valuable and real after that financial transactions will be easier (Sri Dewi Anggadini, 2017). Non-cash payments are faster and less complicated and thus shorten the time for both customers and business owners. Employee division of labor system will be more efficient and save operational costs (Soegoto \& Rafi, 2018). The quality of system is a set of characteristics that can be seen by users as they interact with the system at a given time. SMEs can focus more on developing the business and allocating the funds you have for other things that are more important. 


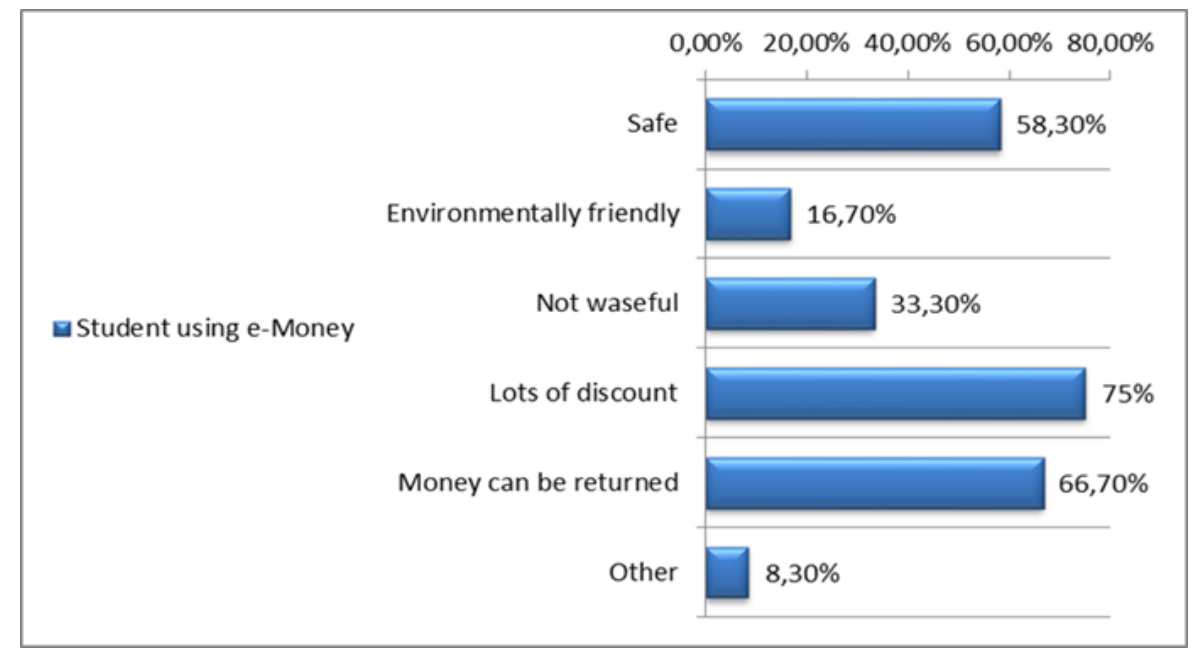

Figure 4. Student using E-Money

Furthermore, when asked why choosing e-Money as a transaction tool, $75 \%$ of the students answered that the discount made it interesting and $66.7 \%$ of them answered that it was because of the cashback. Cashback systems always attract users because if they buy an offer where the buyer accord a percentage of a refund or even given a product but meets certain buy conditions. $33.3 \%$ of them answered that e-money are not wasteful and $16.7 \%$ of them answered that e-money is ecological (Rehman \& Ayoup, 2019 ; Turgaeva el at, 2020). Spending is also more organized because of frequent financial plans, while the existence of E-Money is eco-friendly because it reduces the amount of paper money. After that, it's safe for people and there is no possibility of theft. It would be useful if everything can be done through transactions without cash. 58.3\% of the Samples trusted its safety (Jasim \& Raewf, 2020). Electronic payment systems also refer to the capacity of the security system to reduce fraud and protect users from the theft of funds and personal information. Finally, there is another $8.3 \%$ because they have only used E-money once so they have not been able to feel the impact of E-Money. Every new technology needs to be assessed, analyzed, tested and applied quickly (GW Rahman \& SD Anggadini, 2019).

\section{CONCLUSIONS}

All human beings use money to do transaction and payment. The era development of technology, introduced the concept of money in digital form or e-Money. Digital money is more efficient, friendly and some interesting features attract many people interested in it. E-money has many positive impacts on consumers, especially SMEs. The existence of E-money helps SMEs in shortening their time and can be more focused on developing their business. 


\section{REFERENCES}

Bernal, J. 2017. The recent law on e-money and financial inclusion in Colombia and the regulatory role of the central bank Joaquín Bernal. Journal of Payments Strategy \& Systems, 10(4), pp. 320-321.

GW Rahman, SD Anggadini. 2019. Online Shop Sales Based on E-Commerce. INCITEST. 2019.

Husnunnida, M., \& Alfiana, F. 2019. Improvement of Msme Performance Through Behavior Analysis of Financial Statements Using Accounting Information Technology. Eurasia: Economics \& Business, 27(9), 3505-3515. http:// dx.doi.org/10.1016/j.cej.2014.10.020\%0Ahttp://dx.doi.org/10.1016/ j.apcatb.2013.08.019\%0Ahttp://dx.doi.org/10.1016/j.tsf.2016.12.015

Jasim, Y. A., \& Raewf, M. B. 2020. Information Technology's Impact on the Accounting System. Cihan University-Erbil Journal of Humanities and Social Sciences, 4(1), 50-57. https://doi.org/10.24086/cuejhss.v4n1y2020.pp50-57

Kurniawan, B., Wahyuni, S. F., \& Valentina, T. 2019. The influence of digital payments on public spending patterns. In Journal of Physics: Conference Series. 1402(6) p. 066085.

Lestari, N. D., Lambey, L., \& Tumiwa, J. 2018. The Use of E-Money in State Owned Banks in Manado. Jurnal EMBA: Jurnal Riset Ekonomi, Manajemen, Bisnis dan Akuntansi, 6(4).

Lotz, S., \& Vasselin, F. 2019. A New Monetarist Model of Fiat And E-Money. Economic Inquiry, 57(1), pp. 498-514.

Mustofa, R. H. 2019. Utilization of Electronic Money. In IOP Conference Series: Materials Science and Engineering. 662(2) p. 022013.

Pratiwi, D. F., \& Dewi, C. K. 2018. Factors (Benefits, Trust, Self-Efficacy, Ease of Use, Security) Affecting Consumer's Perception on E-Money in Indonesia. Jurnal Sekretaris dan Administrasi Bisnis, 2(2), pp. 24-37.

Rehman, S., Mohamed, R., \& Ayoup, H. 2019. The Mediating Role of Organizational Capabilities Between Organizational Performance and its Determinants. Journal of Global Entrepreneurship Research, 9(1), 1-23. https://doi.org/10.1186/ s40497-019-0155-5

Rungani, E. C., \& Potgieter, M. 2018. The impact of financial support on the success of small, medium and micro enterprises in the Eastern Cape province. Acta Commercii, 18(1), pp. 1-12.

Soegoto, Eddy Soeryanto. Entrepreneurship Menjadi Pebisnis Ulung Edisi Revisi. Elex Media Komputindo, 2014.

Soegoto, D. S., \& Suprianti, F. 2019. E-Business in The Android Application Based on E-Parking Booking System. Journal of Engineering Science and Technology, 14(5), pp. 2621-2628.

Soegoto, E. S., \& Rafi, M. S. F. 2018. Internet role in improving business transaction. In IOP Conference Series: Materials Science and Engineering. 407(1) p. 012059.

Soegoto, D. S., \& Cica, C. 2018. Design of Web-based Sales Information System on Fashion Shop in Bandung, Indonesia. In IOP Conference Series: Materials Science and Engineering. 407(1) p. 012023. 
Sri Dewi Anggadini. 2017. Improving the Quality of Accounting Information System Through the Availability of User's Competence. Joumal of Engineering and Applied Sciences. 12(11). pp. 9260-9265.

Turgaeva, A. A., Kashirskaya, L. V., Zurnadzhyants, Y. A., Olga, L., Irina, A. P., \& Sevbitov, A. V. 2020. Assessment of The Financial Security of Insurance Companies in The Organization of Internal Control. 7(3), 2243-2254. 